Bulletin of Taras Shevchenko National University of Kyiv. Series "Psychology". № 2(12), pp. 52-56 (2020) УДК 159.923

DOI: https://doi.org/10.17721/BSP.2020.2(12).9
ISSN 1728-3817

(C) Taras Shevchenko National University of Kyiv,

Publishing and Polygraphic Center "Kyiv University", 2020

Anton Kurapov, Ph.D. (Psychology), Assistant Professor ORCID: 0000-0002-1286-9788;

Mykhailo Kandykin, Student

Taras Shevchenko National University of Kyiv, Kyiv, Ukraine

\title{
CONNECTION BETWEen PERSONAL VALUES AND MUSIC PREFERENCES
}

This article describes the main correlations that were obtained between music preferences and personal values. It has been discovered that personal values play a significant role in people's music preferences and they are at the forefront in proposing a map that links personal values to music preferences. According to the results, music preferences can be defined by personal values since people tend to listen to a specific type of music if corresponding values are projected such as conservatism and openness. In this case, music is broken into four preference dimensions which include reflective and complex for folk, jazz, and classical, rebellious and intense comprising of punk, rock, and alternate, conventional and upbeat comprising of pop, country, and soundtracks, and lastly rhythmic and energetic including funk, electronica, hip-hop, and soul. Besides, preferences may be defined by socio-demographic characteristics such as age and gender such that the young people tend to prefer music because of what the other peers listen to and enjoy music in social places such as bars, restaurants, and music festivals, middle-aged people listen to the music of their preferences and at the time of their choosing at homes or while carrying out activities, the aged tend to have less music preference but some cannot do anything without listening to music and therefore have to keep their preference music always. Males tend to focus on certain genres of music such as heavy metal and rock which are associated with cognitive listening and demonstrates a negatively conservative nature of music while females prefer listening to pop music more than males. This article discloses the main results that were obtained in the empirical study of different articles concerning the topic of the relationship between personal values and music preferences. No such research was conducted on Ukrainian-speaking samples before.

Keywords: personal values, music preferences, the psychology of music, music listening.

Introduction. The research aims to determine relationships between personal values, music preferences, and music listening approaches on Ukrainian speaking samples. "Personality traits are increasingly being incorporated in systems to provide a personalized experience to the user," [8, c. 285]. Multiple studies [4, 5; 9; $10 ; 11 ; 13]$ have shown that correlations between music preferences and personality traits do exist. Such connections usually concern different personality traits and affect the music that a particular person chooses to listen to and how a person approaches listening. Some of the personal factors that affect music choice and approach are extraversion/introversion, the image of oneself, and the intention to show this image to others, general intelligence [23]. "The most popular concept in personality research in contemporary psychology is the Big Five model, which specifies five traits: Extraversion which is the state of mainly getting self-gratification from the outside like enjoying human interactions and looking energized and thriving off being around other people, Neuroticism which is the tendency to have a negative feeling on oneself such as self-doubt, anxiety, and depression, Agreeableness which is a personality trait that exhibits itself in the individual's behavioral characteristics such as being warm, kind, tactful, sympathetic, and friendly among other traits, Conscientiousness which consists of well-directed behaviors, thoughtfulness, good control of impulse, being mindful of details and organized, and mindful of deadlines, and Openness includes having a broad range of interests and curious about other people and the world as a general to Experience/Intellect" [30]. Behavior involves the interaction between situational variables and the underlying personality of a person. A person reacts according to how a situation has presented itself. The dimensions, therefore, represent the broad areas of personality traits and the characteristic groupings that occur together in many people such as a sociable person being talkative but not always that the traits occur together. A person may show behaviors across several of the dimensions since personality is varied and complex. Listed factors can affect the general emotional range, complexity, and mood of preferable music. "Individuals do not necessarily prefer music that produces a specific level of arousal. Rather they use music to modulate their arousal and the preferred kind of music changes according to the demands of the situation" [29, c. 592]. For example, extroverted people, who have a vision of themselves as energetic, tend to choose more positive and energetic music [32]. Contextual factors may also play a role in music preferences [25]. Many factors (e.g., contextual, cultural, personal) influence music preferences, but the current research focuses exclusively on personal values (i.e., personal factors). Additionally, according to [19], the rate of software piracy in Ukraine was $83 \%$ in 2013, which was $1 \%$ less than in 2011. Even though it's hard to summarize the trend of music in Ukraine, the media and other digital platforms have given the analysis. The result shows that 416 albums were released in 2018 from a sample of 1000 Ukrainian popular music [1].

Problem Statement. Music is prevalent and omnipresent in our everyday lives. Free platforms, such as YouTube, Facebook among other platforms, contain billions of viewers and listeners every day. According to Music Subscriber Market Shares H1 2019, 3,049 people pay for music streaming services subscriptions, such as Spotify, iTunes, etc. The paper, therefore, seeks to find out why people pay for streaming music and how their values are tied to how they select the music they prefer to listen to and when the music suits their emotional conditions and during human activities. The paper also seeks to find out how music brings satisfaction and peace during emotional breakdowns.

Many people use music to amplify or alter certain emotional states as a way of coping with the different emotional states they find themselves in like heartbreaks, breakdowns of emotions, self-doubt, fear among others $[12 ; 17 ; 18 ; 25 ; 28]$. People listen to "sad" music in a variety of situations such as when their loved ones have passed on when experiencing confusion, or heartbreaks. When they are sad and want to have kind of company to share their emotions with or when they want to experience a range of emotions close to feeling sad but taken out of life circumstances context [32]. It seems that emotions that usually are seen as negative, when taken out of life circumstances and scrutinized through art, can give a person a feeling of aesthetical enjoyment [32].

There is also evidence that stereotypes about listeners of specific genres exist [23]. As people tend to make conclusions about others' personalities based on genre

(c) Kurapov Anton, Kandykin Mykhailo, 2020 
choices, they think that the music they listen to themselves can tell others about who they are and their traits $[4 ; 23]$. Speaking of music as the way of distinction of oneself and others, it can be added that music fans usually wear merchandise clothing and join fan clubs to make kind of statement about themselves.

According to reports of testees $[9 ; 22]$, people frequently listen to music as a background activity or when socializing, for example, driving, cleaning the house, attending clubs, parties, and swimming. Due to this information, it is important to add a difference found in experience when listeners can or cannot choose background music to listen to. When tested subjects were allowed to choose a piece of background music (for example, when driving, cleaning alone, doing homework), they reported experiencing positive emotions more frequently than the situation where the music was chosen for them (at a restaurant, club, etc.) [17]. Therefore, choosing background music for oneself during the various activities, the listeners gain some fulfillment and enjoyment as opposed to being selected the music by someone else. Selecting the music ensures that the person plays the music that they know brings a better feeling to them and enlightens the mood of the activity. Listening to music is therefore a common behavior that many people are involved in from childhood to adulthood and into advance old age. Music serves many adaptive functions for individuals across their lifespan from childhood to adulthood. Some potentially adaptive functional music listening that has been observed from previous qualitative studies include cognitive control, absorption, goalattainment, flow, and transcendence among others.

Generally, music taste alters with age [3; 24]. Teenagers tend to choose contemporary music that their peers listen to, while middle-aged people tend to choose music mainly according to their taste and own sophistication [3]. Middle-aged people listen to music alone or in an intimate environment, while younger people more frequently listen to music in a social environment as clubs or music festivals. While aging, a person can lessen the interest in music, but for people whose lives are heavily affected by music, it may remain an essential part of life as it contributes just more than the infested emotions and feelings. The problem of relations between personality traits and music preferences, while being rarely but firmly studied by Western researchers "A recent survey by Ferwerda et al. [8] of the top journals in six sub-disciplines of psychology revealed that $68 \%$ of subjects were from the US and fully $96 \%$ from 'Western' industrialized nations (European, North American, Australian or Israeli)" remain unstudied in Ukraine.

Methodology. It was decided to use an online test as a method of empirical research for this study. To perform a test, we used 1 ka.si survey website. The link was spread via Facebook and Telegram social media. Before starting, the test participants were told that this test is not obligatory and they can quit it at any time they want, in case they are uncomfortable with the questions, etc.

Factors for adaptive functions of the music listening scale include cognitive regulation, identity, sleep, anxiety regulation, loneliness regulation, appreciation and awe, anger regulation, stress regulation, strong emotional experience, reminiscence, and rumination. We chose to use scales from Chamorro-Premuzic \& Furnham's [4] research as a template for operationalization to measure music listening approaches. To translate scales from English to Ukrainian, we used the back-translation process. There were three scales of approach to music listening:

The scale of emotional listening "M (emot)." For example, a person may state that they listen to music to amplify or alleviate their emotions.

The scale of cognitive listening "M (cog)." It may be used when a person listens to music to appreciate musicians' technique or enjoy music composition sophistication.

The scale of background listening "M (back)" is used when a person listens to music while concentrating on other activities such as traveling, doing house chores, and swimming among other activities.

We chose scales from Schwartz [27] to measure personality traits, a 19-personal values test of S. Schwartz PVQ-R2R. On a diagram, these 19 values are shown in hierarchical order, according to the Schwartz research.

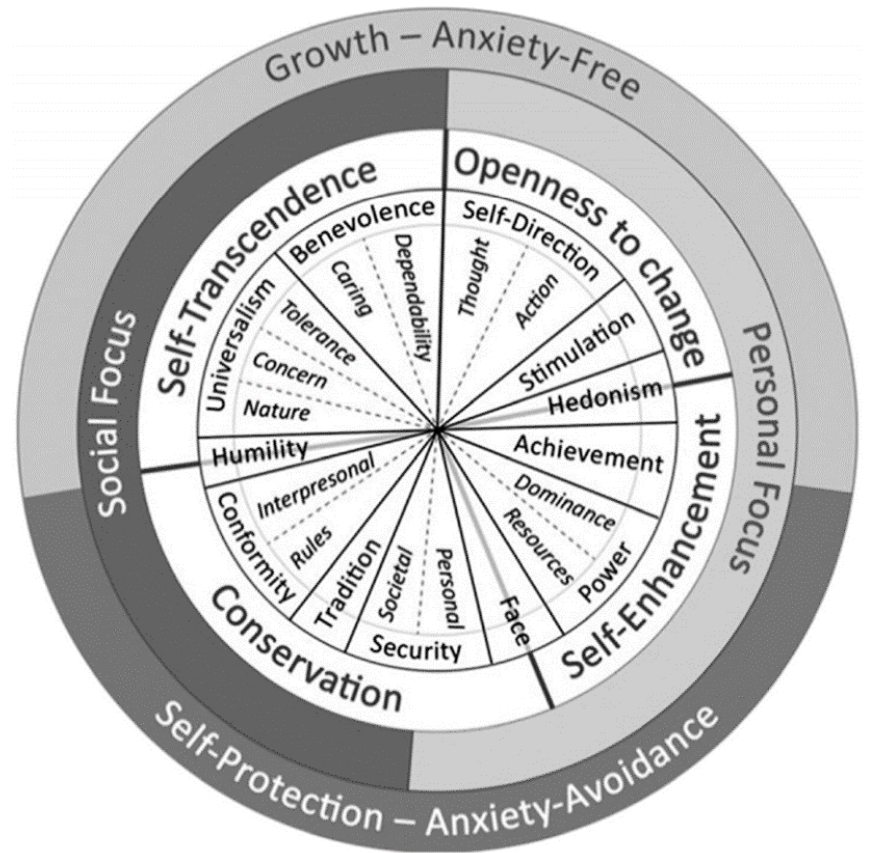

Fig. 1. S. Schwartz PVQ-R2R values [26] 
In total, 384 respondents had begun to pass the test, 280 answered all questions. All respondents who had failed to answer all questions were excluded from the analysis. 209 identified their gender as female, 70 as male, and one respondent stated that they did not identify themselves as any binary gender. The medium age of the respondents is 37.4 . The youngest respondent was 17 years old, and the oldest was 84 .

Respondents were asked about their favorite genres from a sample of the following (jazz, blues, classical, electronic dance music, techno, rap, rock, heavy metal, ambient/movie soundtrack, religious music, country, and folk music). The genres were sampled depending on the following criterion: emotional listening, the scale of cognitive listening, and the scale of background listening. Additionally, they were asked where and how they listen to music (whether they buy records or use music streaming services, listen to the radio, etc.) and whether they have any musical education such as teaching and directing music. If they play any musical instrument (1. Do not have any musical education; 2. Can barely play one or few musical instruments on a fundamental level; 3. Good at playing one or few instruments and have some knowledge in music theory, but did not finish any music school; 4. Finished music school; 5 . Have a degree in music). The test was conducted in the Ukrainian language, which allows viewing the sample with only Ukrainian-speaking samples.

Results. Main component analysis has shown four factors of music taste by the factorial load (inside gaps).
1. Factor 1: jazz (0.9), blues (0.91), and classical music (0.59).

2. Factor 2: electronic dance music $(0.81)$, techno (0.78), and rap (0.72).

3. Factor 3: rock (0.84), heavy metal $(0.87)$.

4. Factor 4: ambient/movie soundtrack $(0.68)$, religious music $(0.63)$, country $(0.57)$, folk music $(0.64)$.

As a result, scales proved their validity on these particular respondent samples. Results across samples have shown that levels of empath are heavily linked with music preferences even within genres and play a great role in the variance proportions over and above personality traits for various dimensions of music preferences. E-S cognitive styles help in differentiating musical preferences. Type $\mathrm{E}$ people prefer mellow music dimensions such as soft rock and adult contemporary. Individuals from type $E$ prefer music that features emotional dept (thoughtful, poetic, and relaxing), negative valence (sad and depressing), and low arousal (sensual attributes, gentle, and warm). Type $S$ people prefer intense dimension music such as hard rock, punk, and heavy metal. Individuals from this type preferred music featuring cerebral depth (complexity), high arousal (thrilling, strong, and tense), and aspects of positive valence (animated). The findings are essential on the autism spectrum, clinicians, and interventions. It can be proven by the scales of inner coherence of Cronbach and Guttman. The results are shown in the table 1.

Inner Coherence Values

Table 1

\begin{tabular}{|l|c|c|}
\hline \multicolumn{1}{|c|}{ Variable } & $\boldsymbol{\alpha}$ Kronbach & $\boldsymbol{\lambda}$ Guttman \\
\hline Type 1 (jazz, blues, classical music) & 0.78 & 0.75 \\
\hline Type 2 (electronic dance music, techno, rap) & 0.71 & 0.63 \\
\hline Type 3 (Rock, Heavy Metal) & 0.74 & Does not count when the sum of points is < 2 \\
\hline Type 4 (Ambient, Folk, Country, Religious music) & 0.6 & 0.54 \\
\hline
\end{tabular}

It was found that correlations between personality traits and music taste do exist. To define relations between music tastes and personal values, 19 values have to be bound into four values of higher-order.

1. Conservation (interpersonal conformity and conformity to the rules; societal and personal security; tradition; shyness; reputation).

2. Openness (self-direction of thought and action; hedonism; stimulation).
3. Transcendence (universalism-tolerance; universalismnature concern; universalism-social concern; benevolencecaring; benevolence-dependability).

4. Enhancement (power-resources; power-dominance; achievement).

Shyness, hedonism, and reputation are bound to not only one higher-order value but few. It is also important to review descriptive statistics of four types of music tastes (factors) and four higher-order values.

Descriptive Statistics of Music Tastes

\begin{tabular}{|l|c|c|c|c|c|}
\hline \multicolumn{1}{|c|}{ Variable } & Mean & SD & Median & Skewness & Kurtosis \\
\hline Factor 1 & 13.85 & 4.03 & 14 & -0.34 \\
\hline Factor 2 & 9.01 & 4.2 & 8 & 0.59 \\
\hline Factor 3 & 8.4 & 3.38 & 8 & -0.09 \\
\hline Factor 4 & 15.62 & 4.3 & 16 & -0.35 \\
\hline Conservation & 87.57 & 13.69 & 88 & -0.94 & -0.1 \\
\hline Openness & 56.99 & 6.16 & 57 & -0.6 & -1.06 \\
\hline Transcendence & 80.26 & 10.03 & 82 & -0.75 \\
\hline Enhancement & 60.26 & 9.31 & 60.5 & 5.43 \\
\hline
\end{tabular}

Spearman Correlational Matrix of Higher Order Values and Music Tastes

Table 3

\begin{tabular}{|c|c|c|c|c|}
\hline \\
\hline & Conservation & Openness & Transcendence & Enhancement \\
\hline Type 1 (jazz, blues, classical music) & 0.003 & 0.16 & 0.16 & -0.09 \\
\hline Type 22 (electornic dance music, techno, rap) & $-0.02^{\star \star \star}$ & 0.15 & $0.04^{*}$ & 0.13 \\
\hline Type 3 (rock, heavy metal) & $-0.25^{\star * *}$ & $0.08^{*}$ & $-0.19^{* * *}$ & $-0.03^{* * *}$ \\
\hline Type 4 (ambient, folk, country, religious music) & $0.03^{*}$ & $0.03^{*}$ & 0.07 & $-0.03^{* * *}$ \\
\hline Pop-music & 0.23 & 0.07 & 0.16 & 0.18 \\
\hline
\end{tabular}

Note: $p \leq 0.05^{*}, p \leq 0.01^{\star \star}, p \leq 0.001^{\star \star *}$ 
Gender differences between approaches to music listening were also discovered. Females recognize familiar melodies better than males since memories of some specific melodies are learned by declarative memory. Significant differences were evident in the cognitive approach to music listening where males dominated in the cognitive approach. Music decreases the response time in females and increases it in males. Music also increases the conflict cost on both genders. The findings show that music has both beneficial and adverse effects on various behavioral measures. Factors such as sex dependency, beneficial and adverse effects have to be considered while using music to rehabilitate neuropsychological disorders. (Student's T-criterion for unrelated samples with Welch correction, d Cohen). Male median index: 22.5 (standard deviation 6.53, kurtosis: -0.47), Female median index: 19.9 (standard deviation: 5.6, kurtosis: $0.44), p=0.004$, d Cohen: 0.44 , it testifies about difference of almost half a standard deviation. There was found no other significant differences in approaches to music listening.

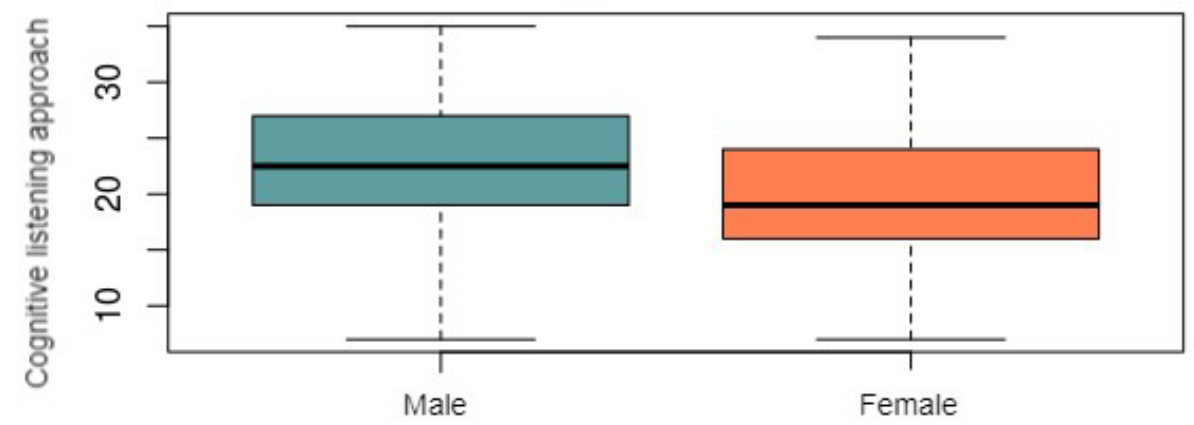

Fig. 2. Gender Differences in Cognitive Music Listening Approach

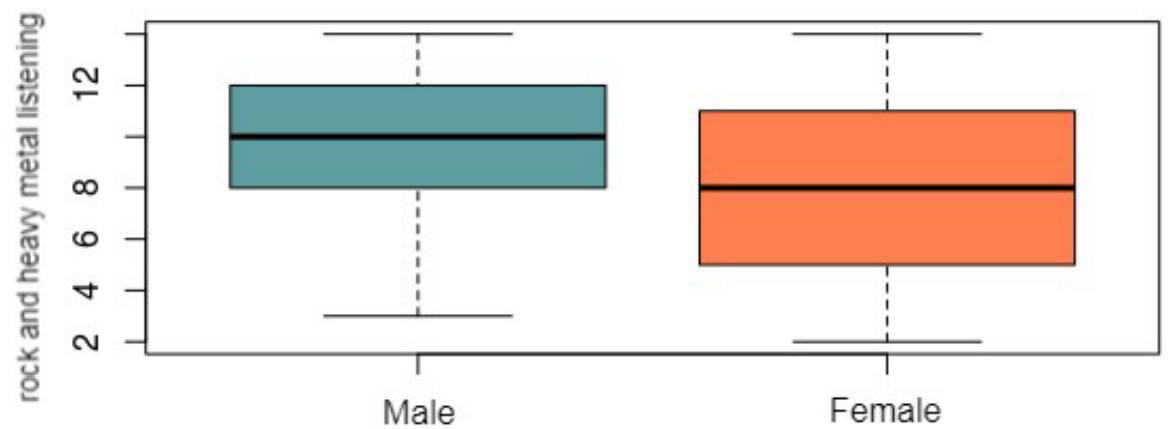

Fig. 3. Gender Differences in Rock and Heavy Metal Listening

Type 1 (jazz, blues, classical music): medium correlations with cognitive listening, musical education (it is important to add that music education has medium correlations only with cognitive listening). A weak correlation coefficient indicates a lower cognitive listening and self-transcendence.

Type 2 (electronic music, techno, and rap): medium correlations with background listening, self-enhancement, and openness to experience.

Type 3 (rock, heavy metal): more common to listen among men, medium and weak correlations coefficient with a lower cognitive listening, negative correlations with conservation and self-transcendence.

Type 4 (ambient, folk, country, and religious): medium correlations with emotional and cognitive listening, weak correlation coefficient with music education.

Pop music: negative correlation with cognitive listening, weak correlation with background listening. Weak correlations with conservation, self-transcendence, self-enhancement, musical education. A little bit more listened by females.

Discussion and Conclusions. This study looked into the correlation between personal value and music preferences listening in Ukraine through analyzing data provided in online music listening traits on the websites and the online platforms. Apart from investigating this correlation, we further needed to know whether the study agrees with the previous result of [8] of personality traits and music genres that were conducted outside Ukraine that had been done previously to determine the correlation between personal values and music preferences. However, by analyzing the online data, we were unable to realize a correlation between personality traits and music preference in Ukrainian since the scientific community has not succeeded in finding any research about the psychology of music preferences even after using search engines Google Scholar and other well-equipped search engines such as zlibrary. Therefore, with no support for our results, it is hard to compare our study's results with previous studies' results since we just used data provided in the online platforms rather than carrying the actual experiment in the field to get first-hand information. Although American and Western European scholars have actively pursued scientific studies of correlations between personality traits and music listening during the last twenty years, there has not been sufficient information to quantify the correlation of music preference and personal values [2; 6; 31].

It seems interesting that the first type of music taste (jazz, blues, classical music) correlates with cognitive listening and musical education. It is possible to assume that jazz, classical music, and blues require broader musical awareness from listeners. It can be added that listeners take music listening seriously because their type of music taste shows a negative correlation with background listening. Perhaps for more experienced listeners, partly educated musicians, music takes a much more significant role than just a fun background for housecleaning.

Rock and Heavy Metal are more often listened to by males, that music taste factor correlates with cognitive listening but correlates negatively with conservation and self-transcendence. Females, on the other hand, tend to 
listen to pop music more than males. Pop-music negatively correlates with cognitive listening and correlates positively with conservation, transcendence, enhancement, musical education. To interpret from the viewpoint where musical taste is a person's opportunity to make a statement or to define an image about oneself towards others and the society at large (Rentfrow \& Gosling, 2003), an assumption can be made: males are more prone to view themselves as rebellious and non-conforming and that is why they listen to rebellious music which depicts negatively on conservation; Females, in contrary, tend to demonstrate more conformity and empathy as they listen to pop music which depicts empathy and other aspects that show concern to others and generality.

\section{References}

1. Ben, B. (2019) Explosion of new Ukrainian music after introduction of protectionist language quotas. Euromaidan press. Retrieved from: http://euromaidanpress.com/2019/10/30/explosion-of-new-ukrainian-musicafter-introduction-of-protectionist-language-quotas/

2. Boer, D. (2009) Music makes the people come together: Social functions of music listening for young people across cultures

3. Bonneville-Roussy, A., Rentfrow, P. J., Xu, M. K., \& Potter, J. (2013) Music through the ages: Trends in musical engagement and preferences from adolescence through middle adulthood. Journal of personality and social psychology, 105(4), 703.

4. Chamorro-Premuzic, T., \& Furnham, A. (2007) Personality and music: Can traits explain how people use music in everyday life? British journal of psychology, 98(2), 175-185

5. Chamorro-Premuzic, T., Swami, V., Furnham, A., \& Maakip, I. (2009) The big five personality traits and uses of music: A replication in Malaysia using structural equation modeling. Journal of Individual Differences, 30(1), 20-27.

6. Delsing, M. J., Ter Bogt, T. F., Engels, R. C., \& Meeus, W. H. (2008) Adolescents' music preferences and personality characteristics. European Journal of Personality: Published for the European Association of Personality Psychology, 22(2), 109-130.

7. Eysenck, H. J. (1993) Creativity and personality: Suggestions for a theory. Psychological Inquiry, 4, 147-178.

8. Ferwerda, B., Tkalcic, M., \& Schedl, M. (2017, July) Personality Traits and Music Genres: What Do People Prefer to Listen To? In Proceedings of the 25th Conference on User Modeling, Adaptation and Personalization (pp. 285-288)

9. Furnham, A., \& Bradley, A. (1997) Music while you work: The differential distraction of background music on the cognitive test performance of introverts and extraverts. Applied Cognitive Psychology, 11, 445-455

10. Furnham, A., \& Strbac, L. (2002) Music is as distracting as noise: The differential distraction of background music and noise on the cognitive test performance of introverts and extraverts. Ergonomics, 45, 203-217.

11. Furnham, A., Trew, S., \& Sneade, I. (1999) The distracting effects of vocal and instrumental music on the cognitive test performance of introverts and extraverts. Personality and Individual Differences, 27, 381-392.
12. Gowensmith, W. N., \& Bloom, L. J. (1997) The effects of heavy metal music on arousal and anger. Journal of Music Therapy, 1, 33-45.

13. Hallam, S., Cross, I., \& Thaut, M. (Eds.). (2011) Oxford handbook of music psychology. Oxford University Press.

14. Henrich, J., Heine, S. J., \& Norenzayan, A. (2010) We agree it's WEIRD, but is it WEIRD enough?. Behavioral and Brain Sciences, 33(2-3), 61-83.

15. Juslin, P. N. (2000) Cue utilization in communication of emotion in music performance: relating performance to perception. Journal of Experimental Psychology, 6, 1797-1813.

16. Juslin, P. N., \& Laukka, P. (2003) Communication of emotions in vocal expression and music performance: Different channels, same code? Psychological Bulletin, 129, 770-814

17. Juslin, P. N., Liljeström, S., Västfjäll, D., Barradas, G., \& Silva, A. (2008) An experience sampling study of emotional reactions to music: listener, music, and situation. Emotion, 8(5), 668.

18. Juslin, P., \& Zentner, M. (2002) Current trends in the study of music and e Musicae Scientiae.

19. Khadka, I. (2015) Software piracy: A study of causes, effects and preventive measures.

20. Konečni, V. J., Brown, A., \& Wanic, R. A. (2008) Comparative effects of music and recalled life-events on emotional state. Psychology of Music, 36(3), 289-308

21. Music Subscriber Market Shares H1 2019 https://www.midiaresearch.com/ blog/music-subscriber-market-shares-h1-2019

22. North, A. C., Hargreaves, D. J., \& Hargreaves, J. J. (2004). Uses of music in everyday life. Music perception, 22(1), 41-77.

23. Rentfrow, P. J., \& Gosling, S. D. (2003). The do re mi's of everyday life: The structure and personality correlates of music preferences. Journal of Personality and Social Psychology, 84(6), 1236-1256

24. Saarikallio, S., \& Erkkilä, J. (2007). The role of music in adolescents' mood regulation. Psychology of music, 35(1), 88-109.

25. Scherer, K. R., \& Zentner, M. R. (2001) Emotional effects of music: Production rules.

26. Schwartz, S. H. (2012) An overview of the Schwartz theory of basic values. Online readings in Psychology and Culture, 2(1), 2307-0919.

27. Schwartz, S. H. (2017) The refined theory of basic values. In Values and behavior (pp. 51-72). Springer, Cham.

28. Sloboda, J. A., \& O'Neil, S. A. (2001) Emotion in everyday listening to music [w:] Music and emotions: Theory and research, red. PN Juslin, JA Sloboda, New York

29. Tekman, H. G. (2009) Music preferences as signs of who we arePersonality and social factors. In ESCOM 2009: 7th Triennial Conference of European Society for the Cognitive Sciences of Music. 592-595.

30. Tychmanowicz, A., Filipiak, S., \& Sprynska, Z. (2019) Extravert individualists or introvert collectivists? Personality traits and individualism and collectivism in students in Poland and Ukraine. Current Psychology, 111. https://doi.org/10.1007/s12144-019-00480-x

31. Vella, E. J., \& Mills, G. (2017) Personality, uses of music, and music preference: The influence of openness to experience and extraversion. Psychology of Music, 45(3), 338-354

32. Vuoskoski, J. K., \& Eerola, T. (2012) Can sad music really make you sad? Indirect measures of affective states induced by music and autobiographical memories. Psychology of Aesthetics, Creativity, and the Arts, 6(3), 204

Надійшла до редколегії 01.09.2020 Рекомендована до друку 15.11.2020

Антон Курапов, канд. психол. наук, асист.

ORCID: 0000-0002-1286-9788;

Михайло Кандикін, студ.

Київський національний університет імені Тараса Шевченка, Київ, Україна

\section{ВЗАЄМОЗВ'ЯЗОК МІЖ ОСОБИСТІСНИМИ ЦІННОСТЯМИ ТА МУЗИЧНИМИ ВПОДОБАННЯМИ}

Представлено основні зв'язки між музичними вподобаннями й особистісними цінностями. Виявлено, що особистісні цінності відіарають важливу роль у музичних уподобаннях людей, адже більшою мірою вони є визначальними для формування преференцій. Згідно з отриманими результатами музичні вподобання можуть визначатися особистісними цінностями, зокрема це стосується консерватизму та відкритості. Музику можна розподілити на чотири виміри: комплексна (джаз і класична); бунтівна та напружена (панк-рок, рок і альтернативні течії); звичайна оптимістична (поп-музика, кантрі та саундтреки); ритмічна (фанк, електроніка, хіп-хоп і соул). Крім того, уподобання можуть визначатися соціально-демографічними характеристиками, такими як вік $і$ стать. Зокрема, молоді люди віддають перевагу музиці через те, що однолітки слухають і насолоджуються нею в соціальних місцях, таких як бари, ресторани та музичні фестивалі; люди середнього віку більшою мірою орієнтуються на індивідуальні вподобання; люди похилого віку мають менше музичних уподобань, але деякі не можуть нічого робити без прослуховування музики як фону. Чоловіки зазвичай зосереджуються на певних жанрах, наприклад "важкому металі" або року, які пов'язані з когнітивним прослуховуванням і демонструють негативноконсервативний характер музики, тоді як жінки віддають перевагу поп-музиці більше, ніж чоловіки. У статті розкрито основні результати дослідження різних аспектів взаємозв'язку між особистісними цінностями та музичними вподобаннями. Раніше таких досліджень на україномовних вибірках не проводили.

Ключові слова: особистісні цінності, музичні вподобання, психологія музики, слухання музики. 